\title{
Pemetaan Pulau Vulkanik Kecil di Indonesia: Studi Pendahuluan Untuk Manajemen Bencana Erupsinya
}

\author{
Agung Hidayat ${ }^{1},{ }^{*}$ Muh Aris Marfai ${ }^{2}$, Danang Sri Hadmoko ${ }^{2}$ \\ ${ }^{1}$ Departemen IImu Geografi, Fakultas Geografi, Universitas Gadjah Mada, Sekip Utara, Bulaksumur, 55281 - Yogyakarta \\ 2Departement Geografi Lingkungan, Fakultas Geografi, Universitas Gadjah Mada, Sekip Utara, Bulaksumur, 55281 - Yogyakarta \\ *korespondensi: arismarfai@ugm.ac.id
}

\section{INFO ARTIKEL}

Riwayat Artikel:

Diterima: 02-06-2019

Disetujui: 23-07-2019

\section{Kata Kunci:}

Pulau vulkanik

Pulau kecil

Erupsi gunungapi

Manajemen bencana

Indonesia

\section{A. LATAR BELAKANG}

Indonesia merupakan negara kepulauan terbesar di dunia dan memiliki 17.504 pulau [1]. Terbentuknya ribuan pulau tersebut tidak dapat dipisahkan dari proses geologis dan vulkanis yang terjadi di Indonesia. Proses geologis dan vulkanis terus terjadi di sepanjang zona

\begin{abstract}
Abstrak: Indonesia merupakan salah satu negara yang dilalui oleh Cincin Api Pasifik. Lebih dari 400 gunungapi berada pada jalur tersebut dan 130 diantaranya masih aktif hingga sekarang. Erupsi gunungapi menghasikan material dari ukuran kecil (abu, pasir, kerikil) hingga ukuran besar (bongkah). Material - material yang keluar dari vent, sebagian akan diendapkan di dekat vent dan perlahan akan membentuk kerucut gunungapi. Penelitian ini bertujuan untuk memetakan pulau vulkanik kecil di Indonesia yang memiliki gunungapi aktif sejak era Holosen. Selain itu juga untuk menganalisis jumlah penduduk yang berada di pulau vulkanik dan sekitarnya untuk melihat jumlah orang yang potensial terdampak erupsi. Identifikasi pulau vulkanik dilakukan dengan interpretasi visual citra satelit yang diverifikasi dengan database gunungapi pada pulau vulkanik yang dipetakan. Hasil identifikasi menunjukkan ada 22 pulau vulkanik dengan catatan erupsi sejak era Holosen. Sebanyak 16 pulau teridentifikasi masih terdapat gunungapi aktif dan sebanyak 6 pulau teridentifikasi terdapat gunungapi dalam masa istirahat. Potensi penduduk terpapar bahaya erupsi pada radius 5 kilometer dari pusat eruspi sebanyak 180.434 orang, radius 10 kilometer dari pusat erupsi sebanyak 373.286 orang, dan radius 30 kilometer dari pusat erupsi sebanyak 1.471 .995 orang. Ada kebutuhan yang nyata untuk melakukan kajian tentang bahaya erupsi di pulau vulkanik di Indonesia, dimana penduduk dan kegiatan ekonominya terus mengalami perkembangan, sehingga berpotensi tinggi terpapar bahaya erupsi. Untuk menyusun strategi pengurangan risiko bencana di pulau vulkanik diperlukan pemahaman tentang wilayah bahaya dan kejadian - kejadian erupsi serta dampaknya pada pulau vulkanik Indonesia dimasa lalu.
\end{abstract}

\begin{abstract}
Indonesia is one of the countries traversed by the Pacific Ring of Fire. More than 400 volcanoes are on this path, and 130 of them are still active today. Volcanic eruptions produce material from small sizes (ash, sand, gravel) to large sizes (bomb). Material coming out of the vent will be partially deposited near the vent and will slowly form a volcanic cone. This study aims to map the small volcanic islands in Indonesia which have active volcanoes since the Holocene era. Besides, it also analyzes the number of people who are on volcanic islands and surrounding areas to see the number of people potentially affected by the eruption. The identification of small volcanic islands uses a visual interpretation of satellite imagery that is verified by volcanic databases on mapped volcanic islands. Identification results show there are 22 volcanic islands with a record of eruption since the Holocene era. Sixteen islands identified with active volcanoes and six islands identified without active volcanoes (dormant). The potential population exposed to the eruption hazard at a radius of 5 kilometers from the crater was 180,434 people, 10 kilometers radius from the crater as many as 373,286 people, and 30 kilometers radius from the crater as many as 1,471,995 people. There is a real need to conduct a study of the eruption hazard on Indonesia's volcanic islands, where the population and economic activities continue to develop, so that the high potential exposure to eruption hazards. Developing disaster risk management on volcanic islands requires an understanding of hazard zones and eruption events and their impact on Indonesia's volcanic islands in the past.
\end{abstract}

tumbukan tiga lempeng tektonik yaitu lempeng Eurasia, lempeng Indo-Australia, dan lempeng Pasifik. Di zona tumbukan antar lempeng tersebut muncul jajaran gunungapi yang jumlahnya mencapai 400 buah, dimana 130 diantaranya tergolong aktif [2]. 
Pulau vulkanik merupakan salah satu konsekuensi logis dari adanya proses vulkanik di zona tumbukan antar lempeng. Pulau vulkanik sesungguhnya merupakan gunungapi yang mengalami erupsi di dasar laut dan secara berangsur - angsur endapan materialnya menumpuk, sehingga bagian puncaknya muncul di atas permukaan laut sebagai pulau [3]. Pulau vulkanik umumnya terbentuk atau merupakan bagian dari busur pulau dalam sistem tektonik. Menurut Condie [3] pulaupulau vulkanik umumnya muncul di dekat punggung samudera atau di cekungan samudera.

Ciri-ciri yang mudah dikenali dari pulau vulkanik adalah dari bentuk pulau dan genesis batuannya. Umumnya bentuk pulau vulkanik menyerupai kerucut, meskipun pada beberapa pulau vulkanik tidak lagi berbentuk kerucut, karena telah hilang pada saat erupsi [4]. Genesis batuan pulau vulkanik dapat dengan mudah dikenali dari singkapan - singkapan batuan yang merupakan produk dari aktivitas vulkanik seperti adanya endapan lava, timbunan lahar, maupun lapisan tefra.

Sebagian pulau vulkanik masih terus tumbuh karena terdapat gunungapi yang masih aktif hingga sekarang. Sebagian lain sudah tidak tumbuh karena sudah tidak terdapat gunungapi aktif baik yang sedang dalam masa istirahat (dormance) atau betul - betul sudah tidak aktif / mati. Contoh pulau vulkanik dengan gunungapi aktif Pulau Ternate, Pulau Siau. Sedangkan contoh untuk pulau vulkanik dengan gunungapi yang sudah tidak aktif adalah Pulau Tidore dan Pulau Hiri.

Pulau vulkanik dengan gunungapi aktif, sudah banyak yang dihuni oleh penduduk. Contohnya di Pulau Ternate, Pulau Rokatenda, dan Pulau Una-Una. Pulau vulkanik dengan gunungapi aktif mempunyai risiko terdampak erupsi lebih tinggi dibanding pulau vulkanik dengan gunungapi yang sudah tidak aktif. Sejarah telah banyak mencatat peristiwa erupsi gunungapi di pulau vulkanik yang berdampak luar biasa kepada masyarakat dan lingkungan. Contohnya adalah erupsi Gunungapi Krakatau tahun 1883 yang memicu gelombang tsunami setinggi 40 meter dan mengakibatkan sekitar 36.500 orang meninggal dunia [2, 5-7]. Tidak hanya itu, korban jiwa sekitar 29.000 orang juga pernah terjadi karena aliran piroklastik pada saat letusan Gunungapi Mount Pelee di Martinique pada tahun 1902 [8, 9].

Terhitung sejak tahun 1700-an, erupsi di pulau-pulau vulkanik di seluruh dunia telah mengakibatkan kematian lebih dari 100.000 orang [10]. Penyebab langsung hilangnya nyawa adalah aliran piroklastik, lahar, landslide / flank collaps, sedangkan penyebab tidak langsung adalah tsunami vulkanik. Salah satu yang meningkatkan risiko terdampak erupsi pada komunitas di pulau vulkanik adalah keterbatasan ruang untuk penyelamatan. Keterbatasan ruang itu berkaitan dengan ukuran pulau vulkanik yang umumnya kecil. Meskipun secara global ukuran pulau vulkanik sangat beragam, mulai dari $<1$ hingga $10.000 \mathrm{~km}^{2}[3]$.
Dalam rangka memudahkan pengelolaan pulau pulaunya, Pemerintah Indonesia mengkategorikan pulau berdasarkan ukurannya menjadi 2 yaitu pulau besar dan pulau kecil. Definisi pulau kecil sebagaimana tercantum dalam Undang - Undang Nomor 1 Tahun 2014 tentang Pengelolaan Pesisir dan Pulau - Pulau Kecil, yaitu sebuah pulau dengan luas kurang dari atau sama dengan 2000 $\mathrm{km}^{2}$ yang mencakup kesatuan ekologisnya (UU No. 1 tahun 2014). Sedangkan pulau besar adalah pulau dengan luas lebih dari $2000 \mathrm{~km}^{2}$. Dengan merujuk pada ukuran - ukuran tersebut maka pulau vulkanik kecil dapat didefinisikan sebagai pulau yang memiliki luas kurang dari atau sama dengan $2000 \mathrm{~km}^{2}$ yang mayoritas bentang lahannya tersusun oleh material vulkanik.

Penelitian pada pulau vulkanik kecil di Indonesia dalam spektrum topik dan metodologi yang luas telah bayak dilakukan, diantaranya di Pulau Siau tentang kapasitas dalam menghadapi bencanan alam [11]; tentang agroforestry di pulau vulkanik kecil [12]. Penelitian lain pernah dilakukan di Pulau Ternate tentang karakteristik erupsi Gunungapi Gamalama [13]; kerentanan fisik dan social masyarakat di Pulau Ternate [14]; dan pemodelan jalur evakuasi karena erupsi Gunungapi Gamalama [15]. Kajian pulau vulkanik paling banyak adalah tentang Pulau Krakatau / Anak Krakatau dengan Gunungapi Krakatau baik dari segi sejarah, dampak, potensi bahaya erupsi, dan potensi bahaya tsunaminya $[5,6,16,17]$.

Penelitian - penelitian yang sudah dilakukan bersifat parsial di beberapa pulau vulkanik. Penelitian penelitian tersebut sesungguhnya adalah bentuk kesadaran akan bahaya pulau vulkanik. Namun demikian eksplorasi mengenai pulau apa saja yang tergolong pulau vulkanik dengan gunungapi yang aktif sejak era Holosen belum pernah dilakukan. Padahal penelitian seperti ini sangat penting untuk dilakukan, mengingat pulau - pulau vulkanik dengan gunungapi aktif di era Holosen masih mempunyai potensi bahaya erupsi dikemudian hari. Ditambah lagi dengan semakin meningkatnya jumlah penduduk yang tinggal di pulau vulkanik, yang dapat meningkatkan risiko terdampak erupsi bagi komunitas yang sesungguhnya tinggal di lereng puncak gunungapi.

Penelitian ini bertujuan untuk memetakan pulau pulau vulkanik kecil di Indonesia yang memiliki gunungapi aktif sejak era Holosen. Selain itu juga memetakan jumlah penduduk di pulau vulkanik kecil dan sekitarnya yang berpotensi terdampak erupsi. Dengan pemetaan ini diharapkan lokasi pulau-pulau vulknik kecil di Indonesia yang memiliki potensi mengalami erupsi dimasa mendatang dapat diketahui sehingga dapat meningkatkan pengetahuan tentang bencana erupsi di pulau vulkanik kecil. Hasil pemetaan ini diharapkan dapat menjadi data awal untuk melakukan menejemen bencana erupsi di pulau vulkanik kecil. 


\section{B. METODE PENELITIAN}

Penelitian ini merupakan penelitian eksploratif. Eksplorasi pulau vulkanik kecil diawali dengan pengumpulan data gunungapi dari Pusat Vulkanologi dan Mitigasi Bencana Geologi [18] dan data dari Simkin dan Siebert [20] terutama yang berkaitan dengan lokasi, nama, dan profil gunungapi. Dari database gunungapi yang ada kemudian dilakukan pengecekan pada aplikasi MAGMA Indonesia (https://magma.vsi.esdm.go.id/) untuk melihat lebih detail situasi dan kondisi gunungapi. Setelah diketahui lokasinya kemudian dilakukan eksplorasi dengan melakukan interpretasi visual pada Citra yang ada pada website MAGMA Indonesia (Gambar 1). Selain itu untuk memudahkan dalam mengindetifikasi pulau vulkanik kecil juga dilakukan pengumpulan data dari Database Gunungapi Dunia yang ada pada website http://volcano.si.edu/ [19] terutama yang berkaitan dengan sejarah erupsi gunungapi, karakteristik, dan jumlah penduduk yang berada sekitar gunungapi. Pemetaan dilakukan dengan bantuan software ArcGIS 10.2 .

\section{HASIL DAN PEMBAHASAN}

\section{Pulau vulkanik di Indonesia}

Hasil identifikasi terhadap pulau - pulau di Indonesia dengan memperhatikan genesis serta keberadaan gunungapi yang pernah erupsi sejak era Holosen maka teridentifikasi ada 22 pulau vulkanik kecil di Indonesia (Gambar 2). Dari 22 pulau vulkanik kecil yang diidentifikasi, sebanyak $73 \%$ (16 pulau) masih terdapat gunungapi aktif dan sisanya sebanyak $27 \%$ (6 pulau) terdapat gunungapi dalam masa dormance (Tabel 1). Sebenarnya pulau vulkanik kecil di Indonesia jumlahnya lebih banyak dari itu, terutama pulau - pulau vulkanik dengan gunungapi yang mengalami erupsi sebelum era Holosen. Namun demikian, fokus kami adalah memetakan pulau vulkanik yang mengalami erupsi sejak era Holosen, karena mempertimbangkan adanya potensi yang tinggi untuk kembali erupsi dikemudian hari.

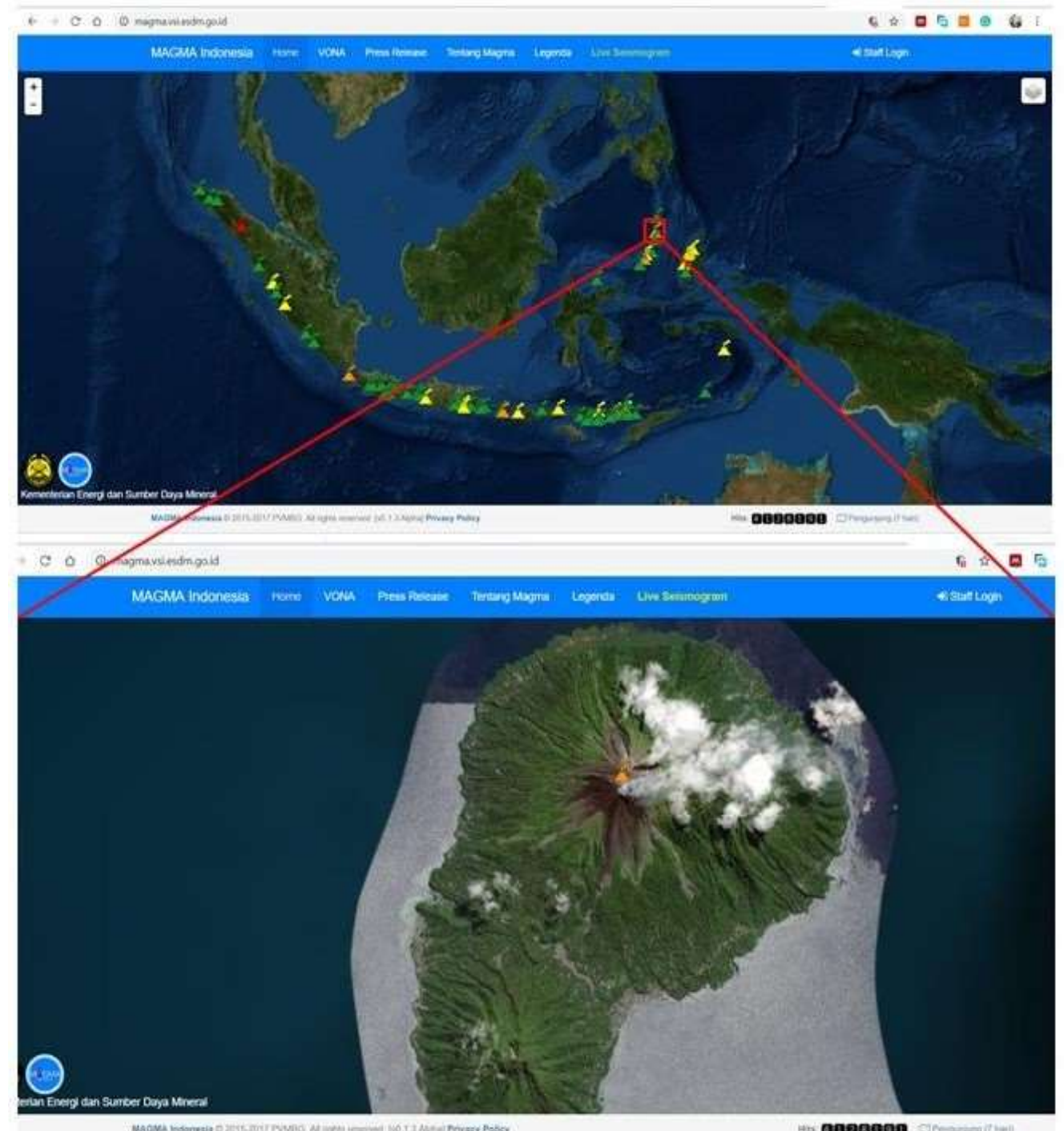

Gambar 1. Aplikasi MAGMA Indonesia (https://magma.vsi.esdm.go.id/) yang menampilkan kondisi terkini gunungapi gunungapi yang ada di Indonesia. Citra pada aplikasi ini diinterpretasi secara visual untuk mengidentifikasi pulau vulkanik dengan gunungapi aktif di Indonesia 
Tabel 1. Pulau vulkanik kecil di Indonesia dengan gunungapi yang mengalami erupsi sejak era Holosen

\begin{tabular}{|c|c|c|c|c|c|c|}
\hline No & Pulau & Koordinat & $\begin{array}{l}\text { Nama } \\
\text { gunungapi }\end{array}$ & $\begin{array}{c}\text { Ketinggian } \\
(\mathrm{mdpl})\end{array}$ & Tipe Gunungapi & Tectonic Settings \\
\hline 1 & Ternate & $0.8^{\circ} \mathrm{LU}, 127,33^{\circ} \mathrm{BT}$ & Gamalama & 1715 & SV; MA & $\mathrm{SZ}, \mathrm{OC}(<15 \mathrm{~km})$ \\
\hline 2 & Hiri & $0.9^{\circ} \mathrm{LU}, 127,32^{\circ} \mathrm{BT}$ & Hiri & 630 & SV & $\mathrm{SZ}, \mathrm{OC}(<15 \mathrm{~km})$ \\
\hline 3 & Makian & $0.32^{\circ} \mathrm{LU}, 127,4^{\circ} \mathrm{BT}$ & Makian & 1357 & SV; PC & $\mathrm{SZ}, \mathrm{OC}(<15 \mathrm{~km})$ \\
\hline 4 & Mare & $0.57^{\circ} \mathrm{LU}, 127,4^{\circ} \mathrm{BT}$ & Mare & 308 & SV & $\mathrm{SZ}, \mathrm{OC}(<15 \mathrm{~km})$ \\
\hline 5 & Moti & $0.45^{\circ} \mathrm{LU}, 127,4^{\circ} \mathrm{BT}$ & Moti & 927 & SV & $\mathrm{SZ}, \mathrm{OC}(<15 \mathrm{~km})$ \\
\hline 6 & Tidore & $0.66^{\circ} \mathrm{LU}, 127,4^{\circ} \mathrm{BT}$ & Tidore & 1730 & SV. CD & $\mathrm{SZ}, \mathrm{OC}(<15 \mathrm{~km})$ \\
\hline 7 & Kayoa & $0.07^{\circ} \mathrm{LU}, 127,4^{\circ} \mathrm{BT}$ & Tigalalu & 422 & SV & $\mathrm{SZ}, \mathrm{OC}(<15 \mathrm{~km})$ \\
\hline 8 & Banda & $4.52^{\circ} \mathrm{LS}, 129,9^{\circ} \mathrm{BT}$ & Banda Api & 596 & CD. SV; TC & $\mathrm{SZ}, \mathrm{OC}(<15 \mathrm{~km})$ \\
\hline 9 & Manuk & $5.54^{\circ} \mathrm{LS}, 130,3^{\circ} \mathrm{BT}$ & Manuk & 257 & SV & $\mathrm{SZ}, \mathrm{OC}(<15 \mathrm{~km})$ \\
\hline 10 & Serua & $6.31^{\circ} \mathrm{LS}, 130,0^{\circ} \mathrm{BT}$ & Legatala & 608 & SV; LD & $\mathrm{SZ}, \mathrm{OC}(<15 \mathrm{~km})$ \\
\hline 11 & Nila & $6.73^{\circ} \mathrm{LS}, 129,5^{\circ} \mathrm{BT}$ & Nila & 781 & SV. CD. PC & $\mathrm{SZ}, \mathrm{OC}(<15 \mathrm{~km})$ \\
\hline 12 & Damar & $7.12^{\circ} \mathrm{LS}, 128,6^{\circ} \mathrm{BT}$ & Wurlali & 868 & SV & $\mathrm{SZ}, \mathrm{OC}(<15 \mathrm{~km})$ \\
\hline 13 & Teun & $6.97^{\circ} \mathrm{LS}, 129,1^{\circ} \mathrm{BT}$ & Teon & 728 & SV & $\mathrm{SZ}, \mathrm{OC}(<15 \mathrm{~km})$ \\
\hline 14 & Gunungapi & $6.64^{\circ} \mathrm{LS}, 126,6^{\circ} \mathrm{BT}$ & Wetar & 282 & SV & $\mathrm{SZ}, \mathrm{OC}(<15 \mathrm{~km})$ \\
\hline 15 & Una Una & $0.16^{\circ} \mathrm{LS}, 121,6^{\circ} \mathrm{BT}$ & Colo & 404 & $\mathrm{SV} ; \mathrm{CD}$ & $\mathrm{SZ}, \mathrm{OC}(<15 \mathrm{~km})$ \\
\hline 16 & Sangihe & $2.3^{\circ} \mathrm{LU}, 125,37^{\circ} \mathrm{BT}$ & Ruang & 725 & SV; LD & $\mathrm{SZ}, \mathrm{OC}(<15 \mathrm{~km})$ \\
\hline 17 & Api Siau & $2.78^{\circ} \mathrm{LU}, 125,4^{\circ} \mathrm{BT}$ & Karangetang & 1797 & SV & $\mathrm{SZ}, \mathrm{OC}(<15 \mathrm{~km})$ \\
\hline 18 & Siau & $3.69^{\circ} \mathrm{LU}, 125,4^{\circ} \mathrm{BT}$ & Awu & 1318 & SV; CD & $\mathrm{SZ}, \mathrm{OC}(<15 \mathrm{~km})$ \\
\hline 19 & Komba & $7.79^{\circ} \mathrm{LS}, 123,6^{\circ} \mathrm{BT}$ & Batu Tara & 633 & SV & $\mathrm{SZ}, \mathrm{OC}(<15 \mathrm{~km})$ \\
\hline 20 & Palue & $8.32^{\circ} \mathrm{LS}, 121,7^{\circ} \mathrm{BT}$ & Rokatenda & 875 & SV; LD & SZ, CT (? ) \\
\hline 21 & Sangiang & $8.2^{\circ} \mathrm{LS}, 119,07^{\circ} \mathrm{BT}$ & Sangeangapi & 1949 & C.; SV & $\mathrm{SZ}, \mathrm{CC}(<15 \mathrm{~km})$ \\
\hline 22 & Anak Krakatau & $6.10^{\circ} \mathrm{LS}, 105,42^{\circ} \mathrm{BT}$ & Anak Krakatau & 813 & CD; SV; PC & $\mathrm{SZ}, \mathrm{CC}(>25 \mathrm{~km})$ \\
\hline
\end{tabular}

Tectonic settings: Subduction Zone (SZ), Oceanic Crust (OC); Crustal

Thickness (CT); Continental Crust (CC),

Types of volcano: Stratovolcano (SV), Caldera (CD), Pyroclastic cone (PC); Lava Dome (LD); Tuff Cone (TC); Maar (MA);

Complex $(C X)$

Sumber: Global Volcanism Programs [19]

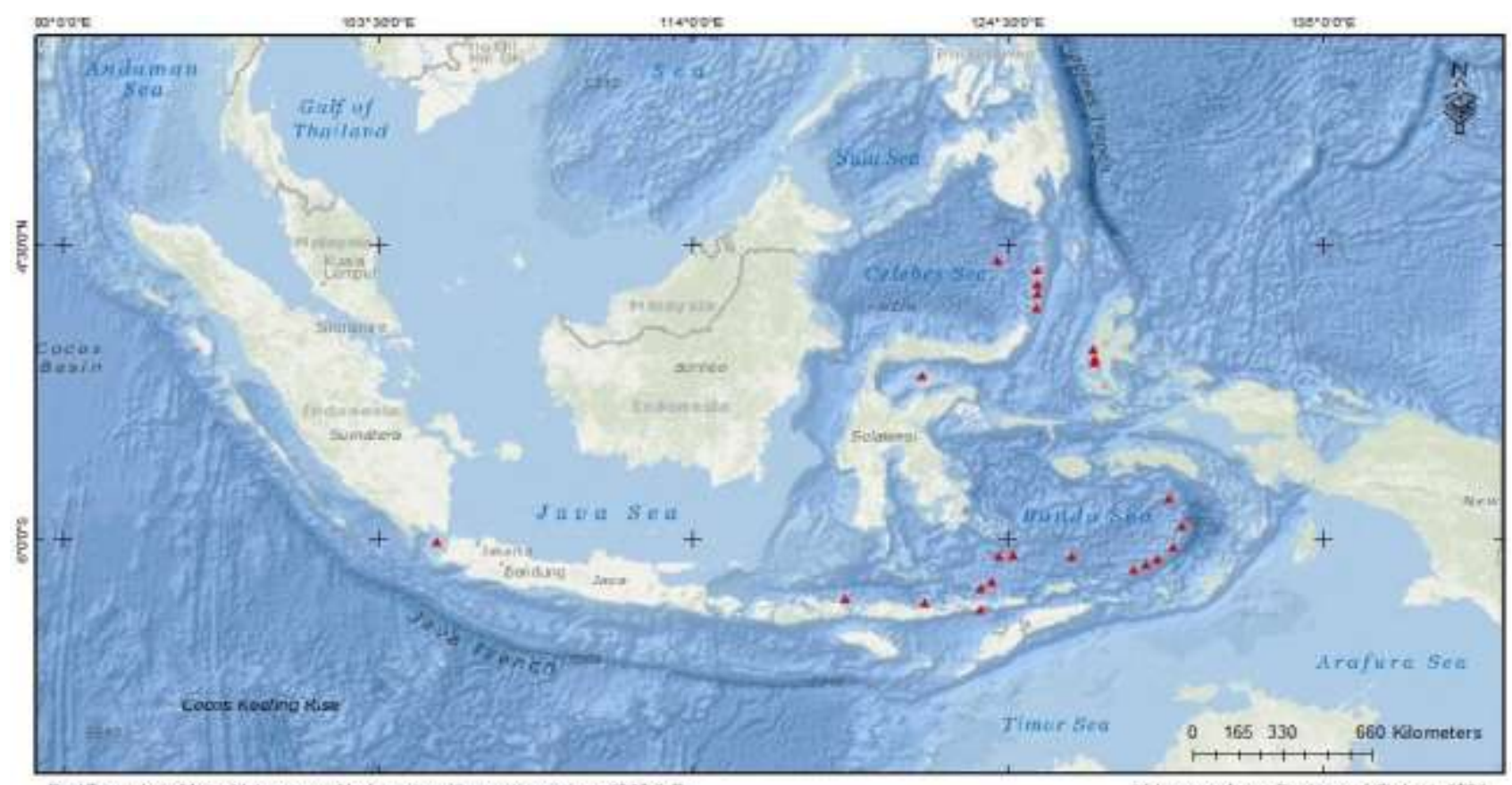

Red Triangle is Major Votcanoes of Indonesia with eruptions since $1900 \mathrm{AD}$

Volcanoes tom. Simikn and Siebert. 1994

Gambar 2. Sebaran Pulau vulkanik kecil di Indonesia dengan gunungapi (segitiga merah)

yang mengalami erupsi sejak era Holosen 
Pulau - pulau vulkanik yang berada di bagian selatan Indonesia terbentuk di zona subduksi antara lempeng Indo-Australia dan Lempeng Eurasia. Sedangkan pulau pulau vulkanik yang berada di bagiam timur Indonesia terbentuk di zona subduksi antara Lempeng Pasifik dan Eurasia (Gambar 2). Pulau - pulau vulkanik itu sebagian besar terbentuk tidak jauh dari oceanic crust $(<15 \mathrm{~km})$. Beberapa terbentuk pada lokasi yang jaraknya lebih dari $25 \mathrm{~km}$ dari oceanic crust. Pulau - pulau vulkanik di Indonesia beserta gunungapinya disajikan pada Tabel 1 .

Pulau - pulau vulkanik di Indonesia umumnya terbentuk dari gunungapi dengan tipe strato (strato volcano). Puncak - puncak gunungapi pada pulau vulkanik mempunyai ketinggian dari atas permukaan laut bervariasi. Pulau vulkanik paling tinggi adalah Pulau Sangiang dengan puncak Gunungapi Sangiangapi pada ketinggian 1.949 mdpl. Nomor dua ada Pulau Api Siau dengan puncak Gunungapi Karangetang pada ketinggian 1.797 mdpl. Pulau vulkanik paling rendah adalah Pulau Manuk dengan puncak Gunungapi Manuk pada ketinggian $257 \mathrm{mdpl}$. Ketinggian masing - masing pulau vulkanik disajikan pada Tabel 1.

\section{Dinamika penduduk di pulau vulkanik kecil}

Masyarakat yang tinggal di wilayah pulau vulkanik dengan gunungapi aktif dapat memperoleh sesuatu yang positif (tanah subur, keindahan bentanglahan gunungapi, dan material hasil erupsi) dan sesuatu yang negatif seperti erupsi [10]. Hal-hal positif itulah yang menyebabkan banyak masyarakat yang tetap tinggal diwilayah gunungapi, meskipun mereka tahu ada bahaya yang mengancam sewaktu-waktu. Erupsi gunungapi sekecil apapun kejadiannya tetap berbahaya bagi orang dan sekitarnya. Di Indonesia umumnya pulau vulkanik itu tidak luas, sehingga tidak banyak tempat yang dapat dikembangkan untuk permukiman. Masyarakat yang menempati pulau vulkanik secara otomatis tinggal tidak jauh dari mulut gunungapi (vent). Semakin dekat dengan mulut gunungapi maka semakin tinggi risikonya terdampak erupsi. Data jumlah penduduk yang tinggal di pulau vulkanik kecil dan sekitarnya pada radius 5 kilometer, 10 kilometer, dan 30 kilometer dari pusat erupsi disajikan pada Tabel 2.

Dari Tabel 2 dapat dilihat bahwa jumlah penduduk Indonesia yang tinggal pada radius 5 kilometer dari pusat erupsi di pulau vulkanik sebanyak 180.434 jiwa. Jumlah penduduk yang tinggal pada radius 10 kilometer sebanyak 373.286 jiwa dan jumlah penduduk yang tinggal pada radius 30 kilometer sebanyak 1.471 .995 jiwa. Jumlah penduduk di Indoneisa secara umum dari tahun ke tahun trennya selalu mengalami peningkatan. Tidak terkecuali pada wilayah pulau vulkanik dan sekitarnya.

Tabel 2. Jumlah penduduk di pulau vulkanik kecil dan sekitarnya

\begin{tabular}{|c|c|c|c|c|c|c|c|}
\hline \multirow{2}{*}{ No } & \multirow{2}{*}{ Nama pulau } & \multirow{2}{*}{$\begin{array}{l}\text { Nama } \\
\text { Gunungapi }\end{array}$} & \multirow{2}{*}{ Terahir erupsi } & \multirow{2}{*}{ Status } & \multicolumn{3}{|c|}{ Jumlah Penduduk (dari crater) } \\
\hline & & & & & Radius $5 \mathrm{~km}$ & Radius $10 \mathrm{~km}$ & Radius $30 \mathrm{~km}$ \\
\hline 1 & Ternate & Gamalama & 2018 & Aktif & 103,429 & 204,820 & 308,691 \\
\hline 2 & Hiri & Hiri & $?$ & Istirahat & 5,65 & 11,454 & 295,487 \\
\hline 3 & Makian & Makian & 1988 & Aktif & 4,986 & 8,466 & 21,36 \\
\hline 4 & Mare & Mare & ? & Istirahat & 889 & 20,821 & 300,717 \\
\hline 5 & Moti & Moti & ? & Istirahat & 3,19 & 5,051 & 89,568 \\
\hline 6 & Tidore & Tidore & ? & Istirahat & 37,379 & 74,12 & 320,483 \\
\hline 7 & Kayoa & Tigalalu & ? & Istirahat & 621 & 2,35 & 7,396 \\
\hline 8 & Banda & Banda Api & 1988 & Aktif & 5,682 & 5,682 & 5,81 \\
\hline 9 & Manuk & Manuk & $?$ & Istirahat & o & o & o \\
\hline 10 & Serua & Legatala & 1921 & Aktif & 58 & 58 & 58 \\
\hline 11 & Nila & Nila & 1968 & Aktif & 200 & 200 & 200 \\
\hline 12 & Damar & Wurlali & 1892 & Aktif & 219 & 365 & 720 \\
\hline 13 & Teun & Teon & 1904 & Aktif & 19 & 102 & 102 \\
\hline 14 & Gunungapi & Wetar & 1699 & Aktif & 2 & 2 & 2 \\
\hline 15 & Una Una & Colo & 1983 & Aktif & 1,897 & 2,025 & 2,025 \\
\hline 16 & Sangihe & Ruang & 2002 & Aktif & 878 & 1,652 & 2,766 \\
\hline 17 & Api Siau & Karangetang & 2019 & Aktif & 892 & 4,478 & 11,066 \\
\hline 18 & Siau & Awu & 2004 & Aktif & 6,409 & 22,655 & 52,725 \\
\hline 19 & Komba & Batu Tara & 2015 & Aktif & 207 & 207 & 207 \\
\hline 20 & Palue & Rokatenda & 2013 & Aktif & 446 & 446 & 5,284 \\
\hline 21 & Sangiang & Sangeangapi & 2019 & Aktif & 204 & 1,155 & 39,301 \\
\hline 22 & Anak Krakatau & Krakatoa & 2019 & Aktif & 7,177 & 7,177 & 8,027 \\
\hline & & Total & & & 180,434 & 373,286 & $1,471,995$ \\
\hline
\end{tabular}


Peningkatan jumlah penduduk membawa konsekuensi pada peningkatan sarana dan prasarana penunjang seperti permukiman, fasilitas umum, dan lain-lain. Menurut Gaudru [10] ketika terjadi erupsi sejumlah besar penduduk dan sarana - prasarana yang berada disekitar gunungapi mempunyai risiko yang tinggi terdampak. Maka dari itu pada kondisi tertentu diperlukan evakuasi ke lokasi yang lebih aman ketika terjadi erupsi di pulau vulkanik. Bahkan, pada beberapa kasus dibutuhkan evakuasi melalui jalur laut ke pulau lain karena wilayah pulau vulkanik yang kecil sudah tidak aman lagi dari ancaman erupsi.

Evakuasi karena bahaya vulkanik memiliki perbedaan yang signifikan jika dibandingkan dengan evakuasi dari bahaya alam lain, karena durasinya yang jauh lebih tidak pasti. Belum lagi, seringkali pulau vulkanik adalah wilayah yang sempit yang mempunyai sejumlah keterbatasan seperti keterbatasan ruang pengembangan, keterbatasan sumberdaya alam, lokasinya yang sulit dijangkau, kesulitan dalam hal transportasi dan komunikasi, keterbatasan jaringan internet, keterbatasan pasar, keterbatasan suplai air bersih, dan ketergantungan tinggi terhadap impor [21].

\section{SIMPULAN DAN SARAN}

Ada 22 pulau vulkanik di Indonesia dengan gunungapi yang tercatat mengalami erupsi sejak era Holosen. Dari 22 pulau vulkanik yang diidentifikasi ada 16 pulau (73\%) yang masih terdapat gunungapi aktif dan ada 6 pulau (27\%) terdapat gunungapi dalam masa istirahat (dormance). Jumlah penduduk Indonesia yang tinggal pada radius 5 kilometer dari puncak gunungapi di pulau vulkanik sebanyak 180.434 jiwa. Jumlah penduduk yang tinggal pada radius 10 kilometer dari sebanyak 373.286 jiwa dan jumlah penduduk yang tinggal pada radius 30 kilometer dari puncak sebanyak 1.471.995 jiwa.

Ada kebutuhan yang nyata untuk melakukan kajian lebih mendalam tentang bahaya erupsi di pulau vulkanik di Indonesia, dimana penduduk dan kegiatan ekonominya terus mengalami perkembangan, yang mempunyai potensi tinggi terdampak erupsi. Untuk menyusun strategi pengurangan risiko bencana di pulau vulkanik diperlukan pemahaman tentang wilayah bahaya dan kejadian - kejadian erupsi serta dampaknya pada pulau vulkanik Indonesia dimasa lalu.

\section{E. UCAPAN TERIMA KASIH}

Penulis pertama mengucapkan terimakasih kepada Lembaga Pengelola Dana Pendidikan (LPDP) atas anugerah Beasiswa LPDP untuk menempuh Pendidikan S3 di Fakultas Geografi, Universitas Gadjah Mada, melalui kontrak nomor PRJ-2912/LPDP.3/2016. Penulis juga mengucapkan terimakasih kepada Kementerian Riset, Teknologi, dan Pendidikan Tinggi untuk dukungan penelitian dan publikasi melalui Hibah Bersaing Nasional skema Penelitian Diseratasi Doktor (PDD).

\section{DAFTAR RUJUKAN}

[1] Martha, S. (2017). The Analysis of Geospatial Information for Validating Some Numbers of Islands in Indonesia. Indonesian Journal of Geography, 49(2), $204-211$.

[2] Mutaqin, B.W., Lavigne, F., Hadmoko, D.S., Malawani, M.N. (2018). Volcanic Eruption-Induced Tsunami in Indonesia: A Review. The 2nd International Conference on Environmental Resources Management in Global Region, at Yogyakarta, Indonesia.

[3] Condie, K.C. (2016). The Crust (Chapter 2 in Earth as an Evolving Planetary System (Third Edition).

[4] Velmurugan, A. (2008). The Nature and Characters of Tropical Islands (Chapter 1), in Editor(s):

Sivaperuman, C., Velmurugan, A., Singh, A.K., Jaisankar, I., Biodiversity and Climate Change Adaptation in Tropical Islands. Academic Press, 2008. Pages 3-30, ISBN 9780128130643, https://doi.org/10.1016/B978-0-12-8130643.00001-6.

[5] Latter, J. H. (1981). Tsunamis of volcanic origin: Summary of causes, with particular reference to Krakatoa, 1883. Bulletin Volcanologique. 44(3), 467490. https://doi.org/10.1007/BFo2600578.

[6] Paris, R., Switzer, A. D., Belousova, M., Belousov, A., Ontowirjo, B., Whelley, P. L., and Ulvrova, M. (2014). Volcanic tsunami: A review of source mechanisms, past events and hazards in Southeast Asia (Indonesia, Philippines, Papua New Guinea). Natural Hazards, 70(1), 447-470. https://doi.org/10.1007/s11069013-0822-8

[7] Brown, S. K., Jenkins, S. F., Sparks, R. S. J., Odbert, H., and Auker, M. R. (2017). Volcanic fatalities database: analysis of volcanic threat with distance and victim classification. Journal of Applied Volcanology, 6(1). https://doi.org/10.1186/s13617017-0067-4

[8] Doocy, S., Daniels, A., Dooling, S., Gorokhovich, Y. (2013). The Human Impact of Volcanoes: a Historical Review of Events 1900-2009 and Systematic Literature Review. PLOS Currents Disasters. Edition 1. 10.1371/currents.dis.841859091a706efebf8a3of4ed7 $\mathrm{A} 1901$

[9] NGDC/WDS (National Geophysical Data Center / World Data Service). (2019). Significant Volcanic Eruptions Database. National Geophysical Data Center, NOAA. doi:10.7289/V5JW8BSH [14 May 2019].

[10] Gaudru, H. (2005). Potential Impacts of Eruption on Volcanic Islands: Global Approach for Volcanic Risk Mitigation. SVEUROP, Geneve

[11] Rampengan, M. M. F., Boedhihartono, A. K., Law, L., Gaillard, J. C., and Sayer, J. (2014). Capacities in Facing Natural Hazards: A Small Island Perspective. International Journal of Disaster Risk Science, 5(4), 
247-264. https://doi.org/10.1007/S13753-0140031-4

[12] Rampengan, M. M. F., Boedhihartono, A. K., Margules, C., Sayer, J., Law, L., Gaillard, J. C., Linh, T. T. M. (2016). Agroforestry on an Active Volcanic Small Island in Indonesia: Prospering with Adversity. Geographical Research, 54(1), 19-34. https://doi.org/10.1111/1745-5871.12148

[13] Hendrajaya, L., Surono, Handayani, G. (1996). A short note on basic behavior of the mount Gamalama's eruption. Jurnal Matematika dan Sains, 1(2), 1 - 14.

[14] Mei, E.T.W., Sari, I.M., Fajarwati, A., Safitri, D. (2017). Assessing the Social Economic and Physical Vulnerabilities to Gamalama Volcano. Proceeding 1st International Conference on Geography and Education (ICGE 2016), Atlantis Press, 33-40. https://doi.org/10.2991/icge-16.2017.7

[15] Syiko, S. F., Ayu R. T., and Yudono, A. (2013). Evacuation Route Planning in Mount Gamalama, Ternate Island-Indonesia. Procedia Environmental Sciences, 17 , 344-353. https://doi.org/10.1016/j.proenv.2013.02.047

[16] Camus, G., Gourgaud, A., and Vincent, P. M. (1987). Petrologic evolution of Krakatau (Indonesia): Implications for a future activity. Journal of Volcanology and Geothermal Research, 33(4), 299316. https://doi.org/10.1016/0377-0273(87)90020-
[17] Giachetti, T., Paris, R., Kelfoun, K., Ontowirjo, B. (2012). Tsunami hazard related to a flank collapse of Anak Krakatau Volcano, Sunda Strait, Indonesia. Geological Society, London, Special Publications 2012, 361, 79-90. doi: 10.1144/SP361.7

[18] PVMBG (Pusat Vulkanologi dan Mitigasi Bencana Geolog), (2011). Data Dasar Gunungapi Indonesia (edisi 2). Jakarta: Badan Geologi.

[19] Global Volcanism Program (2013). Volcanoes of the World, v. 4.7.6. Venzke, E (ed.). Smithsonian Institution. Downloaded 25 Mar 2019. https://doi.org/10.5479/si.GVP.VOTW4-2013

[20] Simkin, T., and Siebert, L. (1994). Volcanoes of the World, Second Edition, A Regional Directory, Gazetteer, and Chronology of Volcanism During the Last 10,000 Years, Geoscience Press, Inc., Tucson, Arizona, in association with Smithsonian Institution, Global Volcanism Program, Washington, D.C., 164176.

[21] Wilkinson, E., Lovell, E., Carby, B., Barclay, J. and Roberton, R. E. A. (2016). The Dilemmas of RiskSensitive Development on a Small Volcanic Island. Resources (5) 21. DOI :10.3390/resources5020021. Licensee MDPI, Basel, Switzerland. 